\title{
Student Group Dynamic Model Based on Understanding in Mathematics Subjects
}

\author{
M. Ivan Ariful Fathoni ${ }^{1 *}$, Anisa Fitri ${ }^{2}$, Hanifahtul Husnah ${ }^{3}$ \\ 1,2,3 Department of Mathematics Education, Universitas Nahdlatul Ulama Sunan Giri, \\ Bojonegoro, Indonesia
}

\section{Article history: \\ Received Nov 21, 2020 \\ Revised May 6, 2021 \\ Accepted May 30, 2021 \\ Kata Kunci: \\ Sistem dinamik, Model matematika, Titik ekuilibrium, Interaksi peserta didik, Proses pembelajaran}

\section{Keywords:}

Dynamical system, Mathematical model, Equilibrium points, Student interaction, Learning process

\begin{abstract}
Abstrak. Penelitian ini membahas tentang interaksi peserta didik dengan sudut pandang pemodelan matematika. Interaksi tersebut melibatkan peserta didik yang memahami dan belum memahami materi mata pelajaran matematika. Proses interaksi antar grup peserta didik dimodelkan dalam suatu sistem persamaan diferensial dua dimensi. Variabel A adalah persentase peserta didik yang memahami materi, dan variabel B adalah persentase peserta didik yang kurang memahami materi. Hasil analisis dinamik diperoleh satu titik ekuilibrium trivial dan tiga titik ekuilibrium non-trivial yang eksis dengan beberapa syarat. Berdasarkan analisis kestabilan titik ekuilibrium non-trivial, diperoleh kondisi tanpa adanya peserta didik yang kurang memahami materi pelajaran matematika. Kondisi inilah yang menjadi tujuan dari penelitian ini, dimana dengan melibatkan interaksi antar peserta didik, dapat meningkatkan keberhasilan proses pembelajaran.
\end{abstract}

\begin{abstract}
This study discusses the interaction of students with a mathematical modeling point of view. This interaction involves students who understand and do not understand mathematics subject matter. The interaction process between groups is modeled in a twodimensional system of differential equations. Variable $\mathrm{A}$ is the percentage of students who understand the material, and variable B is the percentage of students who do not understand the material. The dynamic analysis results obtained by one trivial equilibrium point and three non-trivial equilibrium points exist with several conditions. Based on the stability analysis of the non-trivial equilibrium point, it is found that the conditions without students do not understand mathematics subject matter. This condition is the goal of this study, which involves interaction between students; it can increase the learning process's success.
\end{abstract}

M. I. A. Fathoni, A. Fitri, and H. Husnah, "Student Group Dynamic Model Based on Understanding in Mathematics Subjects”, J. Mat. Mantik, vol. 7, no. 1, pp. 41-50, May 2021.

CONTACT: 


\section{Introduction}

Education means increased skill or development of knowledge and understanding as a result of practice, study, or experience [1]. The importance of education places it at the highest level of human needs. In the introduction to the book written by Klaus Dieter Bieter, Nelson Mandela calls education a powerful force that builds every human being. All countries in the world place education as one of the human rights [2]. Likewise, in Indonesia, education is one area that is the responsibility of the State. Law of the Republic of Indonesia states that: education is a conscious, planned effort to create an atmosphere of learning and the learning process to actively develop their potential to have spiritual strength, self-control, personality, intelligence, noble morals, and skills needed for themselves, society, nation, and state [3] [4].

In general, education aims to increase the nation's intelligence by increasing students' understanding of the subject matter. There are many obstacles for a country to create good quality education, especially in developing countries. One of the problems faced in the world of education is the weak learning process. Students are encouraged to develop thinking skills in the learning process, but in reality, students are only directed to accept and memorize information or knowledge provided by the teacher. The teaching method is one of the supporting factors for the achievement of national education goals [5].

As one of the basic sciences, mathematics has an essential role in the effort to master science and technology. Mathematics in schools needs to function as a vehicle to develop intelligence, abilities, and skills and shape students' personalities [6]. Not a few students think that mathematics is a difficult subject and causes various problems that are difficult to solve, resulting in low student learning outcomes. This results from the lack of interactive mathematics learning methods, where students are only asked to memorize formulas, receive the material, and work on practice questions. Therefore, there is a need for an interactive process between students in the mathematics learning process.

Interaction can be interpreted as communication or a reciprocal relationship between two or more people for a specific purpose [7]. Interaction in a lesson is critical and necessary to help develop students' understanding and achieve educational goals. Learning interaction is an interactive activity of various components to realize the learning objectives set when planning to learn [8]. Learning mathematics as the construction and abstraction of mathematical concepts can be maximized by solving mathematical problems. The problem-solving process will be achieved at a higher level if students work in cooperative groups, especially heterogeneously [9]. In other words, the interaction between student's needs to be done without differentiating each student's abilities.

Based on the learning objectives, students with moderate and low abilities should solve problems and be confident and communicate them effectively. A learning strategy is needed to accommodate student interactions with the learning environment to achieve this goal. One of the learning strategies that support this is a learning strategy that uses cooperative groups, or so-called cooperative learning [10]. In this study, the cooperative learning process was examined by grouping students based on their understanding and mastery of mathematics material.

According to Murdock-Stewart [11], understanding consists of three general categories, which include: (1) understanding structural progress, (2) understanding as a form of knowing, (3) understanding as a process. Students are said to understand something to connect the ideas in their minds and abstract for the next step [12]. So understanding is an organizational process that involves cognitive activities to solve problems. In this study, the measurement of students' understanding was carried out through test scores in mathematics. Students who have a value above Minimum Learning Completeness are 
assumed to have understood the material. In contrast, students who have a value below Minimum Learning Completeness are supposed to have not understood the material.

The development of science in the field of mathematics has a role in helping to analyze the problems of everyday life. One of these problems is in the field of education. Many occurrences in the surroundings can be observed and analyzed in the form of a mathematical model. Mathematical models are models that represent a problem in the real world into mathematical equations [13]. In this study, we analyzed the dynamics of students' level of understanding in mathematics based on time through a modeling approach. In this modeling, the mathematical interpretation of the differential equation system model in the student population will be known based on the level of mathematical understanding.

Several studies on interactions in the learning process have been carried out several times [14]-[16]. In previous research, no one has been able to predict the success of learning in the future. In contrast to previous studies, students' interaction in the learning process was studied from the mathematical modeling perspective. This approach is an alternative method in solving problems in the world of education that have not been widely researched. Mathematical modeling can solve a problem by simplifying cases in everyday life into a mathematical problem where the solution can be obtained. The mathematical model's solution obtained can be used to predict the conditions for the success of the learning process.

\section{Model Formulation}

This study discusses the interaction of students with a mathematical modeling point of view. This interaction involves students who understand and do not yet understand the subject matter of mathematics. The interaction process between groups is modeled in a twodimensional system of differential equations. Variable A is the percentage of students who understand the material, and variable B is the percentage of students who do not understand the material. The compartment model in Fathoni's research [18] is a reference in this study. The basic model in this research is the predator and prey model and the logistic model.

The relationship between predator and prey is the primary basis of studying ecology. One of the important components in this relationship is the speed of predators in preying on their prey. The level of prey per capita of predators or the response function is often called the basis for the predator-prey theory applied in this study. The group that acts as a predator is a group of students who understand mathematics (A). Meanwhile, the group that acts as prey is students who do not understand mathematics (B).

Logistic models are often used to describe the growth rate, including the growth rate of the prey population [19]. The prey population does not always increase continuously, but it depends on the population's size if there is a limit to the environment's carrying capacity. Likewise, the student group does not always experience an increase. The capacity of existing classrooms limits the student group. The logistic model in Putranto's research [20] is applied in this study, where the increase in students' group follows the growth of logistics. 


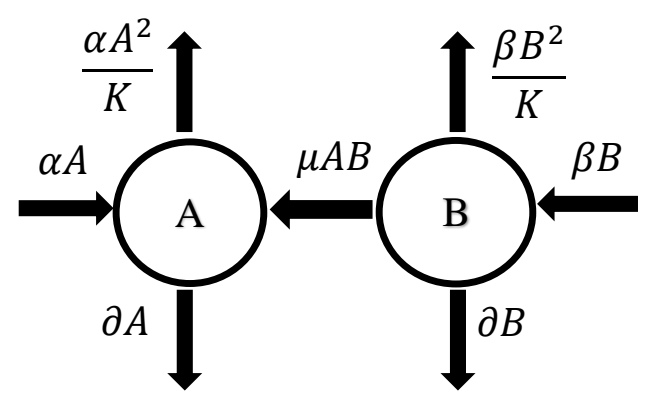

Figure 1. The compartment diagram

By the compartment diagram on Figure 1, we construct a mathematical model with two-dimensional system of the first order ordinary differential equation (ODE). Our model is formulated as the following, see system (1). The parameters used in the model are assumed to be positive, with the information in Table 1. Based on the model in equation (1), a dynamic analysis process is carried out. The discussion of dynamic analysis conducted by Ningsih [21] regarding the growth in the number of students is a reference in the discussion of dynamic analysis in this study. The research carried out includes searching for the equilibrium points, analyzing the equilibrium points' existence, and analyzing the equilibrium points' stability.

$$
\begin{aligned}
& \frac{d A}{d t}=\alpha A\left(1-\frac{A}{K}\right)+\mu A B-\gamma A \\
& \frac{d B}{d t}=\beta B\left(1-\frac{B}{K}\right)-\mu A B-\gamma B
\end{aligned}
$$

Table 1. Parameter description

\begin{tabular}{clc}
\hline Parameter & \multicolumn{1}{c}{ Description } & Unit \\
\hline$\alpha$ & Student group A growth rate. & $1 /$ day \\
$\beta$ & Student group B growth rate. & $1 /$ day \\
$K$ & Carrying capacity of each student group in the class & $\%$ \\
$\mu$ & Rate of interaction between student group A and student group B & $1 / \% /$ day \\
$\gamma$ & Student reduction rate & $1 /$ day \\
\hline
\end{tabular}

\section{Existence of Equilibrium Points}

The system (1) has four equilibrium points consisting of one trivial equilibrium point and three non-trivial equilibrium points. However, we consider the analysis of the three nontrivial equilibrium points. The existence of those equilibrium points is presented in Theorem 1.

Theorem 1. The existences of equilibrium points $E(A, B)$ of system (1)

(i) The equilibrium point $E_{1}=\left(0, \frac{K(-\gamma+\beta)}{\beta}\right)$ exist if $\beta>\gamma$

(ii) The equilibrium point $E_{2}=\left(\frac{K(-\gamma+\alpha)}{\alpha}, 0\right)$ exist if $\alpha>\gamma$ 
(iii) The equilibrium point $E_{3}=\left(\frac{K(-\mu \gamma K+\mu \beta K-\gamma \beta+\alpha \beta)}{\beta \alpha+\mu^{2} K^{2}}, \frac{K(\mu \gamma K-\mu \alpha K-\gamma \alpha+\alpha \beta)}{\beta \alpha+\mu^{2} K^{2}}\right)$ exist if $-\mu \gamma K+\mu \beta K>\gamma \beta-\alpha \beta$ and $\mu \gamma K-\mu \alpha K>\gamma \alpha-\alpha \beta$

\section{Stability Analysis}

We apply the linearization method to determine the stability of the equilibrium point of System (1) and we have the Jacobian matrix as the following,

$$
J=\left[\begin{array}{cc}
\alpha\left(1-\frac{A}{K}\right)-\frac{\alpha A}{K}+\mu B-\gamma & \mu A \\
-\mu B & \beta\left(1-\frac{B}{K}\right)-\frac{\beta B}{K}-\mu A-\gamma
\end{array}\right]
$$

Based on the Jacobian matrix (2), the eigenvalues can be obtained from the characteristic equation $|J-\lambda I|=0$ evaluated at each point of equilibrium.

\subsection{Equilibrium point $E_{1}$}

The Jacobian matrix obtained from the linearization of system (1) near the equilibrium point $E_{1}$ is

$$
J\left(E_{1}\right)=\left[\begin{array}{cc}
\alpha-\frac{\mu K(\gamma-\beta)}{\beta}-\gamma & 0 \\
\frac{\mu K(\gamma-\beta)}{\beta} & \beta\left(1+\frac{\gamma-\beta}{\beta}\right)-\beta
\end{array}\right]
$$

The characteristic equation formed from matrix (3) is

$$
-\frac{(-K \beta \mu+K \mu \gamma-\alpha \beta+\beta \gamma+\lambda \beta)(\gamma-\beta-\lambda)}{\beta}=0
$$

which has the eigenvalues $\lambda_{1}=\gamma-\beta$ and $\lambda_{2}=\frac{K \beta \mu-K \mu \gamma+\alpha \beta-\beta \gamma}{\beta}$. The stability conditions for the equilibrium point $E_{1}$ are obtained when $\gamma<\beta$ and $K \beta \mu-K \mu \gamma<-\alpha \beta+\beta \gamma$.

\subsection{Equilibrium point $E_{2}$}

The Jacobian matrix obtained from the linearization of system (1) near the equilibrium point $E_{2}$ is

$$
J\left(E_{2}\right)=\left[\begin{array}{cc}
\alpha\left(1+\frac{-\alpha+\gamma}{\alpha}\right)-\alpha & -\frac{\mu(-\alpha+\gamma) K}{\alpha} \\
0 & \beta+\frac{\mu(-\alpha+\gamma) K}{\alpha}-\gamma
\end{array}\right]
$$

The characteristic equation formed from matrix (4) is

$$
\frac{(-K \alpha \mu+K \mu \gamma+\alpha \beta-\alpha \gamma-\lambda \alpha)(\gamma-\alpha-\lambda)}{\beta}=0
$$

which has the eigenvalues $\lambda_{1}=\gamma-\alpha$ and $\lambda_{2}=\frac{-K \alpha \mu+K \mu \gamma+\alpha \beta-\alpha \gamma}{\alpha}$. The stability conditions for the equilibrium point $E_{2}$ are obtained when $\gamma<\alpha$ and $-K \alpha \mu+K \mu \gamma<-\alpha \beta+\alpha \gamma$.

\subsection{Equilibrium point $E_{3}$}

Linearization of system (1) near the equilibrium $E_{3}$ produces the characteristic equation as the following 


$$
\begin{aligned}
\frac{1}{K^{2} \mu^{2}+\alpha \beta}(- & \beta(K \mu-\beta+\gamma-\lambda) \alpha^{2} \\
+ & \left((K \mu-\gamma+\lambda) \beta^{2}+\left(-K^{2} \mu^{2}+(\gamma-\lambda)^{2}\right) \beta+K \gamma \mu(K \mu+\gamma-\lambda)\right) \alpha \\
+ & K(\gamma(K \mu-\gamma+\lambda) \beta-K \mu(\gamma-\lambda)(\gamma+\lambda)) \mu)=0
\end{aligned}
$$

The stability of this equilibrium point was analyzed using the Routh Hurwitz criteria and the stability requirements were obtained,

$$
\begin{aligned}
& 0<\frac{-K^{2} \mu^{2}-\alpha \beta}{K^{2} \mu^{2}+\alpha \beta} \\
& 0<\frac{-\beta \alpha^{2}+\left(K \gamma \mu-\beta^{2}+2 \gamma \beta\right) \alpha-K \beta \gamma \mu}{K^{2} \mu^{2}+\alpha \beta} \\
& 0<\frac{((K \mu-\beta+\gamma) \alpha-K \mu \gamma)(\alpha \beta+(K \mu-\gamma) \beta-K \mu \gamma)}{K^{2} \mu^{2}+\alpha \beta}
\end{aligned}
$$

or

$$
\begin{aligned}
& 0>\frac{-K^{2} \mu^{2}-\alpha \beta}{K^{2} \mu^{2}+\alpha \beta} \\
& 0>\frac{-\beta \alpha^{2}+\left(K \gamma \mu-\beta^{2}+2 \gamma \beta\right) \alpha-K \beta \gamma \mu}{K^{2} \mu^{2}+\alpha \beta} \\
& 0>\frac{((K \mu-\beta+\gamma) \alpha-K \mu \gamma)(\alpha \beta+(K \mu-\gamma) \beta-K \mu \gamma)}{K^{2} \mu^{2}+\alpha \beta}
\end{aligned}
$$

\section{Numerical Simulations}

The simulation in this study uses assumption data from a condition at school. However, the research subject of real data in a school is still an open problem in this study. Simulations are carried out based on the assumption of the percentage of the number of students in each group in one class to the total number of students in one education level. The percentage of students who understand mathematics subject matter (Group A) was $20 \%$, while students who did not understand mathematics subject matter (Group B) were $15 \%$. These numbers are assumed to be the initial condition after a teacher conducted a math ability test. Furthermore, through the cooperative learning process, where learning is carried out that focuses on the interaction between students, it is expected to increase students who understand the material.

In the first case, a simulation based on the system's differential equation model (1) is carried out by using the assumed parameter values $\alpha=0.6, \beta=0.7, K=0.4, \mu=$ $0.01, \gamma=0.2$. This case shows a very low interaction process between students, characterized by a very small interaction rate $(\mu)$. Assuming such a parameter value, the only stable equilibrium point is $E_{3}$. The simulation results are obtained in Figure 2. The number of students who understood the material increased from 0.20 to 0.269 . The same thing happened to students who did not understand, which increased from 0.15 to 0.284. The simulation results show that there are still many students who do not understand. It is certainly not a goal in the success of the learning process. 


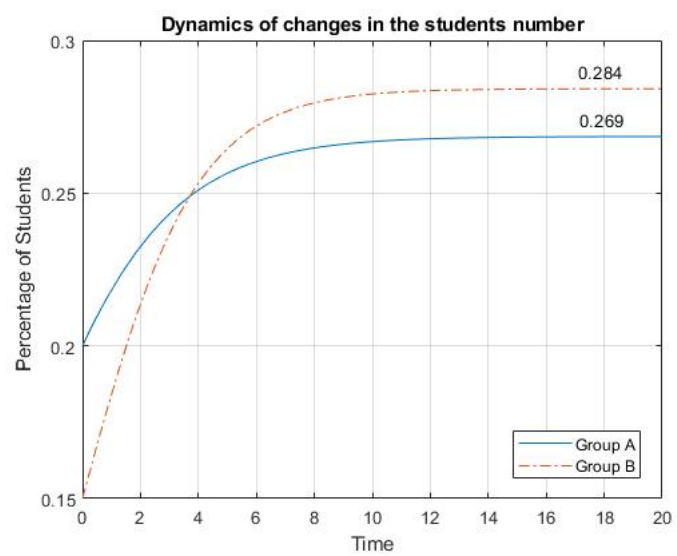

Figure 2. The dynamic of changes in the student's number in each group (case 1)

In the second case, the simulation is carried out based on the assumed parameter values $\alpha=0.6, \beta=0.7, K=0.4, \mu=1.9, \gamma=0.02$. There is a significant increase in the interaction rate from the first case. In this second case, students' movement out of class is also increasingly limited by reducing the student reduction rate $(\gamma)$. Assuming such a parameter value, the only stable equilibrium point is $E_{2}$. The equilibrium point $E_{3}$ becomes not exist. The simulation results are obtained in Figure 3. The number of students in group A increased from 0.2 to 0.387 . The opposite happened in group B, which continued to decrease from 0.15 until no more students did not understand mathematics subject matter. In the second case, the learning process's objective has been achieved but can still be improved.

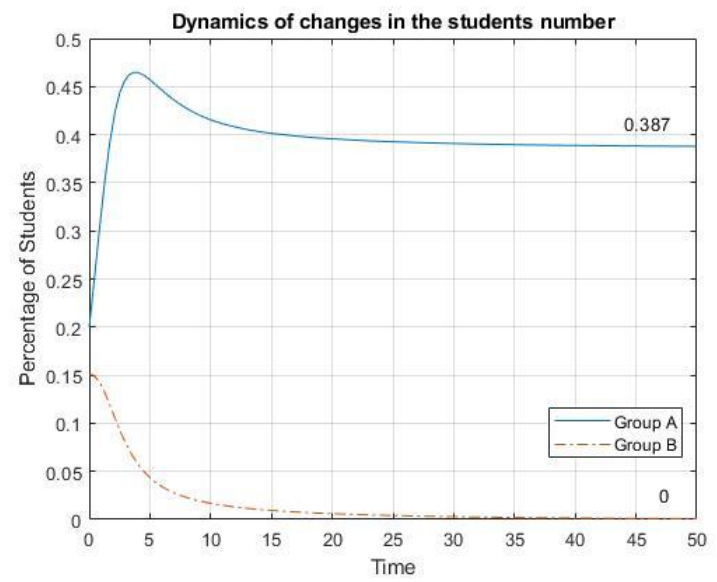

Figure 3. The dynamic of changes in the student's number in each group (case 2)

In the third case, the simulation is carried out based on the assumed parameter values $\alpha=0.9, \beta=0.4, K=0.4, \mu=1.9, \gamma=0.02$. We increase the student group A growth rate $(\alpha)$ and decrease the student group B growth rate $(\beta)$. The simulation results are obtained in Figure 4. Under these conditions, the stability of the equilibrium point is the same as in the second case. However, there was an addition of students who understood (group A) to 0.391, while group B students continued to decrease to zero. Another difference is that the time the solution moves to equilibrium is faster than the second case. In the third case, equilibrium occurs at 16 days. The goal of successful learning happens more quickly. 


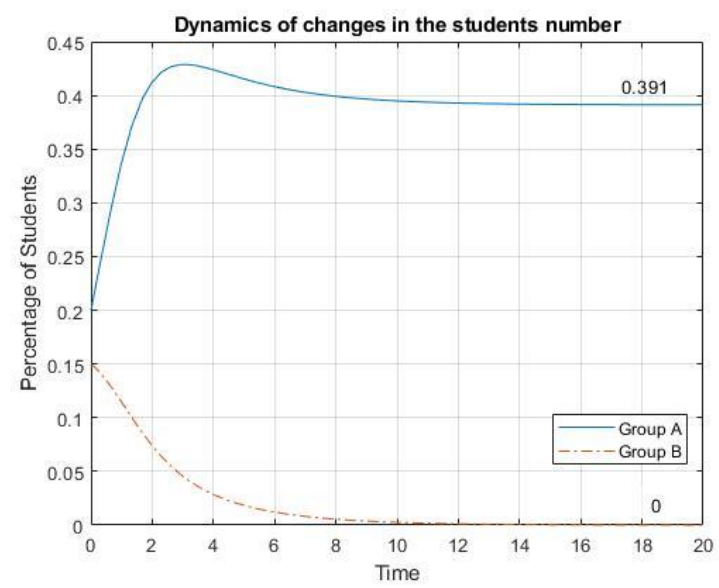

Figure 4. The dynamic of changes in the student's number in each group (case 3)

The simulation results are shown in Figures 1, 2, and 3 explain the process of changing the conditions of students' level of understanding in real-time. Based on this model, predictions can be made when learning success can be achieved, so that teachers can apply appropriate learning methods before starting the learning process. The implication of this study's results can help teachers make teaching more effective and directed under learning outcomes.

\section{Concluding Remarks}

Mathematical modeling can solve a problem by simplifying cases in everyday life into a mathematical problem where the solution can be obtained. This study departs from the background above issues, namely, students' interaction in the mathematics class. This interaction involves two groups of students who understand and do not understand the subject matter of mathematics. The two groups will interact with each other, creating a positive atmosphere in the learning process. The interaction process between groups is modeled in a system of differential equations. The solution of the system of differential equations is expected to reflect the teaching and learning process's success.

The results of the dynamical analysis obtained are strengthened by numerical simulation evidence that supports the analysis. In numerical simulations, it can be concluded that by doing learning that focuses on the interaction between students and limits students' movement out of the classroom, the learning process can run successfully. All students in the class will understand the learning material. Better results are obtained if the teacher adds more students who understand and reduces the more students who do not understand each group. To increase and decrease can be done by moving students from or to another class. Approaching and teaching specifically for some students who do not understand can also be done not to be included in the observation group. It will help accelerate the success of the learning process. The findings in this study can be used as a new research field in the world of education.

\section{References}

[1] E. Humphrey, Encyclopedia Internasional. New York: Grolier, 1975.

[2] E. Bruce-Jones, "Beiter, 'The Protection of the Right to Education by International Law," MenschenRechtsMagazin, vol. 3. Universitätsverlag Potsdam, pp. 325-326, 2006. 
[3] Sekretariat Negara RI, Undang-Undang Republik Indonesia No.20 Tahun 2003 Tentang Sistem Pendidikan Nasional. 2003, p. 2.

[4] Sekretariat Negara RI, Undang-Undang Republik Indonesia No.14 Tahun 2005 Tentang Guru dan Dosen. 2005.

[5] M. Yusuf, Pengantar Ilmu Pendidikan, 1st ed. Palopo: Lembaga Penerbit Kampus IAIN Palopo, 2018.

[6] A. C. Sari, "Meningkatkan Kemampuan Pemecahan Masalah Matematis Siswa SMP dengan Model Pembelajaran Think Talk Write," J. Math. Educ. Sci., vol. 1, no. April, pp. 7-13, 2018.

[7] N. K. Roestiyah, Masalah Pengajaran Sebagai Suatu Sistem. Rineka Cipta, 1994.

[8] D. Kuhn, V. Shaw, and M. Felton, "Effects of dyadic interaction on argumentive reasoning," Cogn. Instr., vol. 15, no. 3, pp. 287-315, 1997.

[9] D. P. Martin and S. E. Rimm-Kaufman, "Do student self-efficacy and teacherstudent interaction quality contribute to emotional and social engagement in fifth grade math?," J. Sch. Psychol., vol. 53, no. 5, pp. 359-373, Oct. 2015, doi: 10.1016/j.jsp.2015.07.001.

[10] R. Leikin and O. Zaslavsky, "Facilitating student interactions in mathematics in a cooperative learning setting," J. Res. Math. Educ., vol. 28, no. 3, pp. 331-354, 1997, doi: $10.2307 / 749784$.

[11] V. Murdock-Stewart, Making sense of students' understanding of fractions: An exploratory study of sixth graders' construction of fraction concepts through the use of physical referents and real world representations. The Florida State University, 2005.

[12] J. Piaget and E. Duckworth, "Genetic Epistemology," Am. Behav. Sci., vol. 13, no. 3, pp. 459-480, Jan. 1970, doi: 10.1177/000276427001300320.

[13] I. Ismanto and M. I. A. Fathoni, "Strategi Pencegahan Endemi HIV/AIDS dengan Menggunakan Pemodelan Matematika," MAJAMATH J. Mat. dan Pendidik. Mat., vol. 2, no. 1, pp. 32-41, 2019.

[14] M. Uliyandari, I. N. Candra, and S. Sumpono, "Analisis Tingkat Pemahaman Siswa Kelas XII IPA SMA Negeri Kota Bengkulu untuk Mata Pelajaran Kimia,” 2014.

[15] L. E. Febriyanti, M. Martosudiro, and T. Hadiastono, "Pengaruh Plant Growth Promoting Rhizobacteria (PGPR) terhadap Infeksi Peanut Stripe Virus (PStV), Pertumbuhan dan Produksi Tanaman Kacang Tanah (Arachis hypogaea L.) Varietas Gajah," J. Hama dan Penyakit Tumbuh., vol. 3, no. 1, p. pp-84, 2015.

[16] D. S. N. Afifah, "Interaksi belajar matematika siswa dalam pembelajaran kooperatif tipe STAD," Pedagog. J. Pendidik., vol. 1, no. 2, pp. 145-152, 2012.

[17] C. Febriyanti and S. Seruni, "Peran minat dan interaksi siswa dengan guru dalam meningkatkan hasil belajar matematika," Form. J. Ilm. Pendidik. MIPA, vol. 4, no. 3, 2015.

[18] M. I. A. Fathoni, Gunardi, F. A. Kusumo, and S. H. Hutajulu, "Mathematical model analysis of breast cancer stages with side effects on heart in chemotherapy patients," in AIP Conference Proceedings, 2019, vol. 2192, doi: 10.1063/1.5139153.

[19] W. E. Boyce, R. C. DiPrima, and D. B. Meade, Elementary differential equations. 
Jurnal Matematika MANTIK

Vol. 7, No. 1, May 2021, pp. 41-50

John Wiley \& Sons, 2017.

[20] Y. W. Putranto, "Analisis Titik Ekuilibrium dan Solusi Model Interaksi PemangsaMangsa Menggunakan Metode Dekomposisi Adomian," Universitas Sanata Dharma, 2017.

[21] W. Ningsih and R. Khusniah, "Analisis Dinamis Model Matematika Pertumbuhan Jumlah Mahasiswa Program Studi Pendidikan Matematika STKIP PGRI Pasuruan," J. Math. Educ. Sci., vol. 1, no. October, pp. 61-66, 2018. 